This study was supported by grants from Carl-Bertel Nathhorst Foundation, the Swedish Medical Research Council B70-21x1021-05, the National Institutes of Health, Bethesda, U.S.A. (GM 13978-05), the Association of the Swedish Pharmaceutical Industry, and by funds from Karolinska Institutet.

The polynomal analysis of variance was performed by $\mathrm{Mr}$. Jan Lindell.

REFERENCES

Alexanderson, B., Evans, D. A. P., and Siöqvist, F. (1969). British Medical fournal, 4, 764 .

Berry, R., and Turner, P. (1968). British fournal of Psychiatry, 114, 203.

Borgå, O., Azarnoff, D. L., Plym Forshell, G., and Sjöqvist, F. (1969). Biochemical Pharmacology, 18, 2135.

Borgå, O., Hamberger, B., Malmfors, T., and Sjöqvist, F. (1970). Journal of Pharmacology and Experimental Therapeutics. In press.

Carlsson, A. (1965). In Handbuch der experimentellen Pharmakologie, ed. O. Eichler and A. Farah, vol. 19, p. 529. Berlin, Springer.

Cronholm, B., and Ottosson, J.-O. (1960). Acta Psychiatrica Scandinavica, 35, Suppl. No. 145 , p. 69.

Cronholm, B., and Ottosson, J.-O. (1963). British fournal of Psychiatry, 109, 251 .
Freyschuss, U., Siöqvist, F., Tuck, D., and Åsberg, M. (1970a). Pharmacologia Clinica, 2, 68.

Freyschuss, U., Sjöqvist, F., and Tuck, D. (1970b). Pharmacologia Clinica, 2,72 .

Green, D. M. (1964). Annals of Internal Medicine, 60, 255.

Hamilton, M. (1959). British fournal of Medical Psychology, 32, 50.

Hammer, W., and Brodie, B. B. (1967). Journal of Pharmacology and Experimental Therapeutics, 157, 503.

Hammer, W., Ideström, C.-M., and Sjöqvist, F. (1967). In Antidepressan Drugs, ed. S. Garattini and M. N. G. Dukes, p. 301. Amsterdam, Excerpta Medica.

Rose, J. T., Leahy, M. R., Martin, I. C. A., and Westhead, T. T. (1965) British fournal of Psychiatry, 111, 1101 .

Schildkraut, J. J., and Kety, S. S. (1967). Science, 156, 21.

Sjöqvist, F., et al. (1968). In Toxicity and Side Effects of Psychotropic Drugs, ed. S. B. de C. Baker, J. R. Boissier, and W. Koll, p. 246. Amsterdam, Excerpta Medica.

Sjöqvist, F., Hammer, W., Borgå, O., and Azarnoff, D. L. (1969). In Collegium Internationale Neuro-psychopharmacologicum: The Present Status of Psychotropic Drugs, ed. A. Cerletti and F. J. Boré, p. 128. Amsterdam, Excerpta Medica.

Stewart, J. A., and Mitchell, P. H. (1968). British fournal of Psychiatry, $114,469$.

Winer, B. J. (1962). Statistical Principles in Experimental Design, p. 306. New York, McGraw-Hill.

\title{
Comparative Trial of Nutrizym in Chronic Pancreatic Insufficiency
}

\author{
R. P. KNILL-JONES, ${ }^{*}$ M.B., M.R.C.P. ; H. PEARCE, $† ;$ J. BATTEN, $\ddagger$ M.D., F.R.C.P. \\ ROGER WILLIAMS, $\$ M.D., F.R.C.P.
}

British Medical fournal, 1970, 4, 21-24

\begin{abstract}
Ummary: A cross-over trial of pancreatic replacement therapy was carried out in 12 adults with chronic pancreatic insufficiency. The standard enteric-coated preparation, Pancrex V forte, was compared with Nutrizym, which has an enteric-coated core of pancreatic extract and a shell of bromelains-a mixture of proteolytic enzymes derived from the stem of the pineapple.

Nutrizym was significantly more effective than Pancrex $V$ forte in improving fat absorption, and reduced faecal weight. Protein digestion was assessed by measuring the urinary excretion of hydroxyproline after a gelatin meal. Nutrizym produced an earlier and significantly higher peak in hydroxyproline excretion than Pancrex $\mathrm{V}$ forte, but the cumulative effect was similar. The value of bromelains was investigated by including a period on the Nutrizym core alone. This was similar to Pancrex $V$ forte in improving fat absorption but had less effect on protein digestion, suggesting that the beneficial effect of Nutrizym compared with Pancrex $V$ forte was due to the added bromelains, and not to differences in enzyme content or enteric coating.
\end{abstract}

\section{Introduction}

Several reports have shown that pancreatic extracts can increase body weight, fat, and nitrogen absorption (Buckle, 1965; Harris et al., 1955) and can improve absorption curves (Mullinger, 1968). The response is often incomplete, however, even if large doses are given throughout the day (Jordan and Grossman, 1959), and even if sodium bicarbonate is added (Glaessner and Sigel, 1904; Veeger et al., 1962; Haro and Faloon, 1964). Plant and bacterial enzymes have been incorporated in some pancreatic preparations to improve their effectiveness (Goebell and Bode, 1969). A mixture of brome-

\footnotetext{
* Research Fellow, Liver Unit, King's College Hospital, London S.E.5.

† Research Technician, Liver Unit, King's College Hospital, London S.E.5. Consultant Physician, St. George's Hospital, London S.W.1., and Bromp-
ton Hospital, London S.W.3. $\checkmark$ Consultant Physician and Director, Liver Unit, King's College Hospital,
}

lains and pancreatin is available in two preparations (Nusser and Donath, 1968; Schultis and Wagner, 1968), one of which is Nutrizym (Merck). Bromelains is a mixture of proteolytic enzymes found in the stem of the pineapple (Ananas comosus); it has maximal proteolytic activity between $p H 3$ and 8 , and is stable at $p \mathrm{H} 2.0$ for a short period. Studies in vitro have shown that its effect in the digestion of casein at $p H 3.3$ is similar to that of pepsin and at $p H 6.0$ is similar to that of trypsin (Hennrich et al., 1965). Nutrizym has an enteric-coated core containing concentrated pancreatic extract, surrounded by a layer of bromelains and a sugar coating.

We describe here a cross-over trial comparing Nutrizym with Pancrex V forte (pancreatin, B.P.), which is the most widely used of the pancreatic replacement preparations available in the British Isles. The effect of the added bromelains was also investigated by including in the trial a period on Nutrizym core, which was identical in appearance to Nutrizym but contained enteric-coated pancreatin alone.

\section{Design of Trial}

Fourteen outpatients ( 3 female and 11 male) were admitted to the trial: two middle-aged patients with chronic pancreatitis and 12 (aged 15-29) with cystic fibrosis. The latter were chosen because they had considerable steatorrhoea even while taking Pancrex V forte (10 patients) or pancreatin granules (two patients). Other treatment was unaltered during the trial. Each patient was in the trial for three months and received Pancrex, Nutrizym, and Nutrizym core, each for one month in random order. A tablet of Nutrizym contained 50 mg. of bromelains. The amount of pancreatin in a tablet of Nutrizym was greater than in Pancrex V forte, and the doses given with each of the three main meals in a day were either three tablets of Pancrex $V$ forte or two tablets of the Nutrizym preparations. At the end of the trial the three preparations were assayed in vitro. Each tablet of Nutrizym and Nutrizym core was found to contain: trypsin 2,500 units, lipase 8,100 units, and amylase 18,000 units; the corresponding figures for Pancrex $\mathrm{V}$ forte were 1,230, 4,000, and 9,600 units respectively. 


\section{Fat Analysis and Gelatin Tolerance Test}

A 72-hour collection from the last weekend in each month was analysed for faecal fat by the method of van de Kamer et al. (1949). Patients remained on their normal diet during the trial and recorded stool frequency daily and stool weight on three days in each week. The fat intake over collection periods and the preceeding two days was estimated from a record of food intake kept by the patient.

The gelatin tolerance test was used to assess protein digestion since it is independent of food intake. Gelatin contains about 14"', of hydroxyproline, which is absorbed following digestion as a mixture of short peptides, an amount proportional to blood levels being excreted in the urine (Prockop et al., 1962). At the end of each test month the patient was put on a low gelatin diet (Bronstein et al., 1966; Cerda et al., 1968) and after completion of a basal 24-hour urine collection $25 \mathrm{~g}$. of powdered gelatin (B.P.) in water was drunk immediately after taking the appropriate dose of trial tablets. Urine was voided two-hourly for eight hours and $350 \mathrm{ml}$. of fluid was taken every two hours. Finally, urine was collected for the remaining 16 hours of the 24 -hour test period. Aliquots were analysed for total urine hydroxyproline by the method of Kivirrikko et al. (1967). The basal hydroxyproline excretion (derived from the endogenous breakdown of collagen) was subtracted from each two-hour excretion. Thus the excess excreted in every two-hour period indicates the effectiveness of added pancreatic replacement therapy.

\section{Results}

Two men did not complete the trial: one with cystic fibrosis withdrew because of a change in place of employment and the other had chronic pancreatitis with diabetes controlled by tolbutamide and asked to be withdrawn from the trial while on Nutrizym because of increasing glycosuria and lethargy. These symptoms improved after he returned to his usual dose of Pancrex V forte, and the episode may have been due to improved digestion while on Nutrizym. The mean change in each criterion for each of the three drug comparisons was tested for significance with the paired $t$ test.

\section{Patient Preference}

Analysis of the patients' weekly assessment of changes in general health and in chest symptoms, and also of their subjective preferences (Table I) for the preparations, showed no $\therefore$ gnificant differences. Two of the patients who preferred Nutrizym spontaneously reported improvement in stool odour. Five patients complained of mild abdominal pain (which is not uncommon in cystic fibrosis), but this did not occur while they were on Nutrizym. No significant changes in patients' weight, haemoglobin, and serum proteins occurred during the trial.

\section{Stool Frequency and Weight}

The first four days in each month were excluded to eliminate the effect of previous treatment. Analysis of individual stool frequency records showed significant changes in some patients on different preparations (Table II). Stool weight was decreased by both Nutrizym and Nutrizym core in comparison with Pancrex V forte (Table III), but the differences were not statistically significant.

\section{Fat Intake and Excretion}

The daily fat intake on Nutrizym and Pancrex $V$ forte were similar but were higher while on Nutrizym core (Table III), suggesting that Nutrizym core was not as effective as
TABLE I.-Preferences of 10 Patients for the Different Tablets During the Trial. Two Gave No Particular Preference

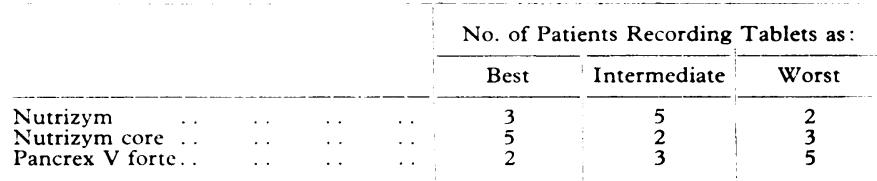

TABLE II.-Analysis of Stool Frequency for Individual Patients, Showing Number with Statistically Significant Alterations in Stool Frequency $(P<0.025)$ in Each Drug Comparison

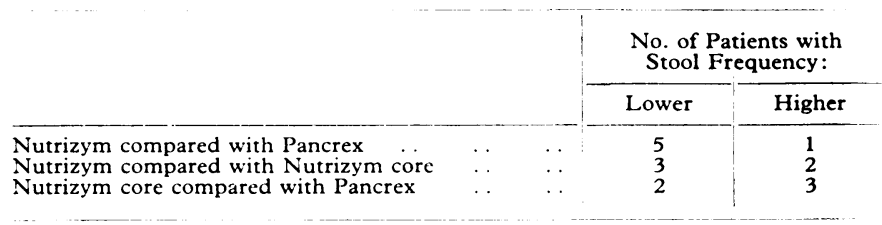

TABLE III.-Summary of Measurements on Steatorrhoea. Mean Values $( \pm 1$ Standard Error) While on the Three Preparations are Given

\begin{tabular}{|c|c|c|c|}
\hline & Nutrizym & Nutrizym Core & Pancrex V Forte \\
\hline $\begin{array}{l}\text { Daily stool weight (g./day). . } \\
\text { Fat intake (g./day) } \\
\text { Fat output (g./day) } \\
\text { Fat absorption ("., } \\
\text { Fat in faeces ("). }\end{array}$ & $\begin{array}{r}444 \cdot 2 \div 47 \cdot 6 \\
101 \cdot 5 \div 8 \cdot 5 \\
42 \cdot 5 \div 5 \cdot 2 \\
57 \cdot 3 \\
\end{array}$ & $\begin{array}{r}461.7 \\
119.0+12.6 \\
54.9 \\
53.1\end{array}$ & $\begin{array}{r}513 \cdot 8 \pm 51 \cdot 2 \\
102 \cdot 9 \pm 7 \cdot 2 \\
57 \cdot 3 \pm 7 \cdot 5 \\
44 \cdot 2 \pm 6 \cdot 5\end{array}$ \\
\hline $\begin{array}{lllll}\text { weight) } & \ldots & \ldots & \end{array}$ & $13 \cdot 0: 1 \cdot 25$ & $13 \cdot 6 \pm 1.4$ & $14.4 \pm 1.6$ \\
\hline
\end{tabular}

TABle IV.-Results of Gelatin Tolerance Tests in 12 Patients on 3 Preparations and also Rtsults Without Pancreatic Supplementation (Mean values \pm standard error)

\begin{tabular}{|c|c|c|c|c|}
\hline & Nutrizym & $\begin{array}{l}\text { Nutrizym } \\
\text { Core }\end{array}$ & $\begin{array}{l}\text { Pancrex } \\
\text { V Forte }\end{array}$ & $\begin{array}{l}\text { Test with } \\
\text { no Tablets }\end{array}$ \\
\hline $\begin{array}{l}\text { 24-hour basal excretion } \\
\text { of hydroxyproline } \\
\text { (mg.hour).. } \\
\text { Urine volumes during }\end{array}$ & $1 \cdot 58+0 \cdot 24$ & $1 \cdot 64: 0 \cdot 28$ & $1.64 \times 0.19$ & $1 \cdot 83 \pm 0 \cdot 19$ \\
\hline $\begin{array}{l}\text { 8-hour collection } \\
\text { period (ml.) }\end{array}$ & $1,168=147$ & $1,251 \quad 140$ & $1,228+117$ & $1,232 \pm 152$ \\
\hline $\begin{array}{l}\text { Excess } \\
\text { excreted in } 8 \text { hours } \\
\text { (mg.) } \\
\text { Maximum hydroxypro- }\end{array}$ & $52 \cdot 1: 5 \cdot 7$ & $44 \cdot 4: 5 \cdot 2$ & $49 \cdot 5: 6 \cdot 57$ & $32 \cdot 4 \pm 3 \cdot 8$ \\
\hline $\begin{array}{l}\text { line excreted in any } \\
2 \text {-hour period (mg.) }\end{array}$ & $11 \cdot 32: 1.36$ & $8 \cdot 70=1.03$ & $10 \cdot 03 \div 1 \cdot 32$ & $6 \cdot 78 \pm 1 \cdot 03$ \\
\hline
\end{tabular}

Nutrizym in suppressing the polyphagia often associated with untreated pancreatic insufficiency (May and Lowe, 1949). Most patients had considerable steatorrhoea during the trial (Table III). The mean fat output while on Nutrizym was 14.9 g./day less than on Pancrex $V$ forte $(P<0.025)$. It was $12.5 \mathrm{~g}$./day less than on Nutrizym core (Fig. 1), and this difference approached significance $(0.1>P>0.05)$. The difference in the daily fat output between treatments was not due to variation in dietary fat intake, as similar changes were shown by the percentage fat absorption (Table III). On Nutrizym the fat absorption was $13.1 \%$ higher than on Pancrex $\mathrm{V}$ forte $(\mathrm{P}<0.05)$.

\section{Gelatin Tolerance Test}

The average increase in the total hydroxyproline excre:ion for all patients in the eight hours after ingestion of gelatin was slightly higher with Nutrizym than with Pancrex V forte (Table IV). It was $17 \%$ higher on Nutrizym compared with Nutrizym core (the least effective preparation in this test), but this difference was not significant. The mean value for the highest two-hour hydroxyproline excretions was obtained with Nutrizym and was $2.6 \mathrm{mg}$. greater than with Nutrizym core $(\mathrm{P}<0.05)$.

Composite curves were constructed from the mean values of hydroxyproline excretion for the 12 patients for each treatment (Fig. 2). The value for Nutrizym in the two- to four- 


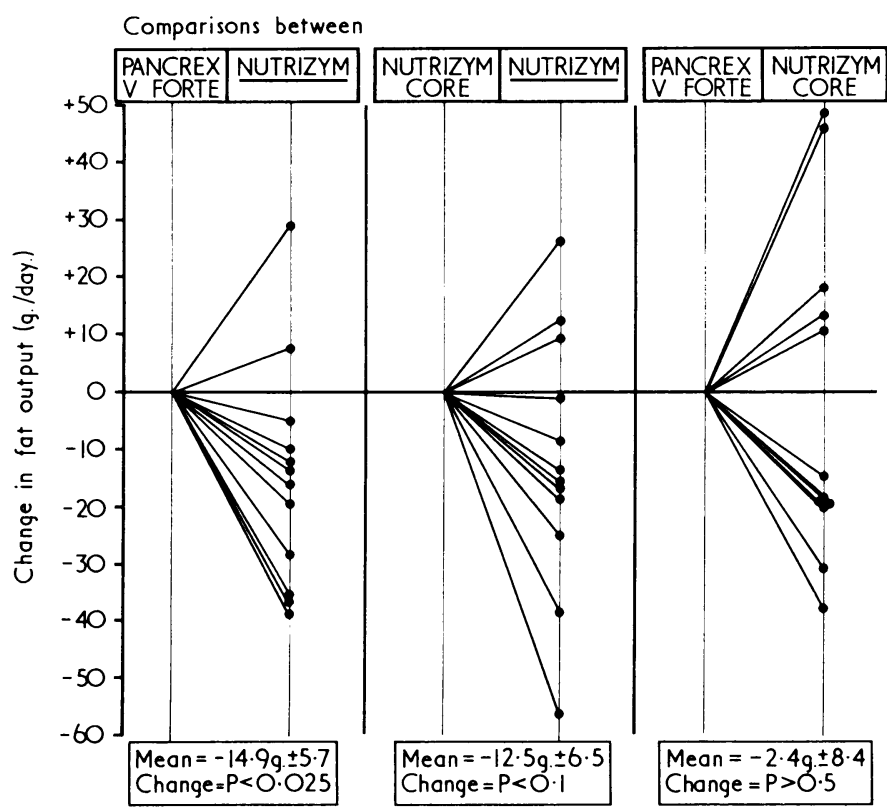

FIG. 1.-Change in fat output, showing a significant reduction when Nutrizym is compared with Pancrex V forte.

hour collection period was $2.9 \mathrm{mg}$./hour higher $(\mathrm{P}<0.01)$ and the four- to six-hour value $1.9 \mathrm{mg}$./hour lower $(P<0.05)$ than for Pancrex V forte. This suggests that the proteolytic action of Nutrizym starts earlier and finishes before that of Pancrex $\mathrm{V}$ forte, though the total effect over eight hours is similar (Table IV). The values in the final 16-hour collection were not significantly higher than corresponding basal values (Table IV), indicating that digestion and absorption of gelatin was complete within eight hours.

Comparison of Values Obtained with and without Replacement Therapy.-After the trial each patient had a further gelatin tolerance test for which pancreatic replacement therapy had been stopped for 24 hours, allowing assessment of the patients' endogenous protein digestion. Each preparation produced a higher composite curve than the one obtained without therapy (Fig. 2). Nutrizym core showed the least change, and though it was consistently better than the test without tablets, in no two-hour period was the improvement significant. Both Nutrizym and Pancrex V forte, however, showed a definite improvement (Fig. 2). Results were also
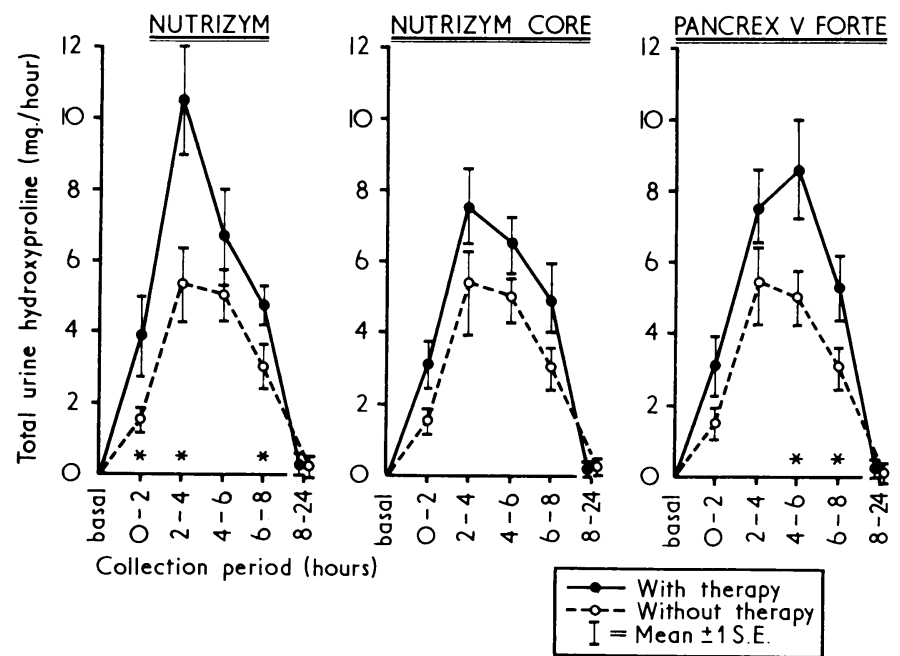

FIG. 2.-Mean total hydroxyproline excretion from 12 patients for each period, corrected for basal excretion, after ingestion of gelatin (25g.). The curve is increased by the addition of each pancreatic replacement preparation. * Indicates individual two-hour periods of hydroxyproline excretion which show significantly higher values (paired $t$ test, $P<0.05$ ) due to the effect of pancreatic replacement therapy. expressed as the eight-hour total hydroxyproline excretion, which showed a significant increase with Nutrizym $(P<0.005)$ and with Pancrex $\mathrm{V}$ forte $(\mathrm{P}<0.025)$. Nutrizym core was less effective $(0.2>P>0.1)$.

\section{Discussion}

There have been several comparisons of the effectiveness of pancreatic replacement preparations, both in vitro (Giulian et al., 1967; Goebell and Bode, 1969) and in dogs (Pairent et al., 1969). In one study in which activity was measured by 19 different assays Nutrizym was the most effective of the 20 compounds tested (Berndt and Müller-Wieland, 1968); but few clinical trials have compared the efficacy of available pancreatic preparations in man. Matthews and Spector (1961) found little difference between Panteric granules, Viokase, and Cotazym in separate groups of patients with cystic fibrosis; their study did not have a cross-over design, and patient variation may have obscured differences in effectiveness of the preparations.

In the present trial, as in other reports, fat absorption did not return to normal-partly because submaximal doses of pancreatic extracts were used in order to make it easier to detect differences between the preparations, and partly because patients with cystic fibrosis have, in addition to pancreatic exocrine insufficiency, impaired mucosal transfer of products of digestion (Matthews and Spector, 1961), probably due to a thick mucinous layer covering the small-intestinal mucosa (Freye et al., 1964).

The significantly lower fat output obtained with Nutrizym is unlikely to be solely due to a higher lipase content than Pancrex V forte (as measured in vitro), since Pancrex V forte and Nutrizym core (containing the same lipase activity as Nutrizym) gave similar results. Likewise the lower fat output is also unlikely to be due to differences in the enteric coating of Nutrizym and Pancrex $\mathrm{V}$ forte. Bromelains in Nutrizym may have contributed to this, though the effect must have been indirect, because bromelains given alone to patients with pancreatic insufficiency produce a slight rise in fat excretion and a moderate fall in nitrogen excretion (Kugener et al., 1968). The most likely explanation for this effect of bromelains may be that the enteric coating of Nutrizym is made less efficient, thus allowing release of lipase higher in the small intestine. On the other hand, the enteric coating of Nutrizym core (which has no bromelains) prevents early release of its pancreatin contents, resulting in similar effectiveness of Nutrizym core and Pancrex $\mathrm{V}$ forte in vivo. The gelatin tolerance test results, showing a difference between Nutrizym and Nutrizym core, show that bromelains also may produce an improvement in protein digestion.

It is concluded that Nutrizym has significant advantages over Pancrex V forte in improving fat absorption, and may also reduce stool weight and percentage fat content. In some patients it reduced stool frequency. There was also an improvement in protein digestion as measured by the gelatin tolerance test. A few patients noted symptomatic improvement and preferred Nutrizym because of the smaller number of tablets required for equivalent treatment.

We would like to acknowledge the help of Drs. D. Price-Williams, W. J. Bludau, and E. Groll and the support of E. Merck, Darmstadt, Germany, during this investigation. We are also indebted to $\mathrm{Mr}$. $M$. Curwen for designing the trial and to Miss P. Carden for the analyses of dietary fat intake.

\section{REFERENCES}

Berndt, W., and Müller-Wieland, K. (1968). Ernährungs-Umschau, 15, 304. Bronstein, H. D., Haeffner, L. J., and Kowlessar, O. D. (1966). Gastroenterology, 50, 621 .

Buckle, R. M. (1965). British Fournal of Clinical Practice, 19, 683.

Cerda, J. J., Brooks, F. P., and Prockop, D. J. (1968) Gastroenterology, 54, 358.

Freye, H. B., Kurtz, S. M., Spock, A., and Capp, M. P. (1964). Journal of 
Giulian, B. B., Singh, L. M., Mansfield, A. O., Pairent, F. W., and Howard, J. M. (1967). Annals of Surgery, 165, 564 .

Glaessner, K., and Sigel, J. (1904). Berliner klinische Wochenschrift, 41, 440. Goebell, H., and Bode, C. (1969). Medizinische Welt, 15, 877.

Haro, E. N., and Faloon, W. W. (1964). Clinical Research, 12, 207.

Harris, R., Norman, A. P., and Payne, W. W. (1955). Archives of Disease in Childhood, 30, 424 .

Hennrich, N., Hoffman, A., and Lang, H. (1965). Arzneimittel-Forschung, $15,434$.

Jordan, P. H., jun., and Grossman, M. I. (1959). Gastroenterology, 36, 447.

Kivirrikko, K. I., Laitinen, O., and Prockop, D. J. (1967). Analytical Biochemistry, 19, 249.

Kugener, H., Bergman, O., and Beck, K. (1968). Zeitschrift für Gastroenterologie, 6,430 .
Matthews, L. W., and Spector, S. (1961). Pediatrics, 27, 351.

May, C. D., and Lowe, C. U. (1949). Fournal of Pediatrics, 34, 663.

Mullinger, M. (1968). Pediatrics, 42, 523.

Nusser, E., and Donath, H. (1968). Medizinische Klinik, 63, 142.

Pairent, F. W., Trapnell, J. E., and Howard, J. M. (1969). Annals of Surgery, $170,737$.

Prockop, D. J., Keiser, H. R., and Sjoerdsma, A. (1962). Lancet, 2, 527.

Schultis, K., and Wagner, E. (1968). Deutsche medizinische Wochenschrift, 93, 1685 .

van de Kamer, J. H., ten Bokkel Huinink, H., and Weyers, H. A. (1949). fournal of Biological Chemistry, 177, 347 .

Veeger, W., Abels, J., Hellemans, N., and Nieweg, H. O. (1962). New England fournal of Medicine, 267, 1341.

\section{Use of Amantadine in Parkinson's Disease. Results of a Double-blind Trial}

VERA DALLOS,* M.B., B.S., B.SC. ; KENNETH HEATHFIELD, † M.D., F.R.C.P. ; PATRICIA STONE, $\ddagger$ B.PHARM., M.P.S. F. A. D. ALLEN, $\subseteq$ F.P.S., D.B.A.

British Medical fournal, 1970, 4, 24-26

\begin{abstract}
Ummary: In a four-week double-blind trial of 62 patients with Parkinsonism 29 were treated with amantadine and 33 with a placebo. Modest but statistically significant improvement was observed in the first group, optimum benefit occurring after the first two weeks. Patients' reactions to the drug were favourable in $79 \%$, and side effects were insignificant. Though amantadine appears to be a useful additive drug in the treatment of Parkinsonism, its value as a single treatment is as yet undetermined.
\end{abstract}

\section{Introduction}

Schwab, England, Poskanzer, and Young (1969) observed the beneficial effect of amantadine in a patient with Parkinsonism who had been given the drug as a prophylactic against influenza. They subsequently reported its use in 163 cases. Their observations have since been confirmed by Parkes, Zilkha, Calver, and Knill-Jones (1970) in a controlled trial of 37 patients treated for two weeks.

The aim of the present study was to investigate a larger group of patients and to determine the place of amantadine in the treatment of Parkinsonian symptoms.

\section{Patients and Methods}

Sixty-two outpatients ( 24 men and 38 women) with Parkinsonism were admitted to trial. Twenty-nine were allocated randomly to receive amantadine and 33 to receive placebo capsules. The randomization was stratified with regard to age, sex, previous thalamotomy, and initial severity, as judged by our scoring system for rigidity, tremor, akinesia, and functional disability, and for tests of motor facility (occupational therapy tests). The age of the patients ranged from 43 to 74 years in the amantadine group (group A) and from 40 to 74 years in the placebo group (group B). There were 10 men (34\%) in group $A$ and $14(43 \%)$ in group $B$.

Out of the 62 patients, 58 completed the trial-28 in group A and 30 in group B. One patient in group A died of pneumonia and three in group $B$ failed to attend after the initial assessment, after the second week, and after the third week, respectively. In group A 17 cases were judged to be of idiopathic paralysis agitans, five were arteriosclerotic, and six post-encephalitic; seven patients had had previous thalamo-

\footnotetext{
* Medical Registrar.

† Consultant Neurologist.

$\ddagger$ Deputy Chief Pharmacist.

Group Pharmacist.

Whipps Cross Hospital, London E.11.
}

tomy. In group B 17 cases were idiopathic, six arteriosclerotic, and seven post-encephalitic; nine patients had had previous thalamotomy.

Scores for severity of tremor, rigidity, and akinesia were given by a clinical observer and those for functional disability and occupational therapy tests were allocated by the occupational therapist. Neither the clinician nor the occupational therapist knew which patients were on the test drug; this was known only by the pharmacist who dispensed the capsules according to the instructions of the statistician.

\section{Scoring System}

Scores for severity of rigidity and tremor were allotted on the following basis: severe $=3$, moderate $=2$, slight $=1$, and nil $=0$. Severity of rigidity and tremor were recorded for each of the four limbs and for the trunk. The possible total score for each sign was 15.

Akinesia was assessed by nine factors: eight on a threepoint severity scale $(0,1$, or 2$)$ and one on a five-point scale $(0,1,2,3$, or 4$)$, the total score being 20 :

$\begin{array}{ll}\text { Mask-like facies } & 0-2 \\ \text { Dribbling gait } & 0-2 \\ \text { Shuffling gait } & 0-2 \\ \text { Festination } & 0-2 \\ \text { Feet stick to ground } & 0-2 \\ \text { Attitude of flexion } & 0-2 \\ \text { Loss of arm swinging } & \\ \text { (R) } & 0-2 \\ \text { (L) } & 0-2 \\ \text { Weak voice } & 0-4\end{array}$

Assessments were made at weeks $0,1,2,3,4$, and 8 by the clinician.

Social disability was assessed by 10 aspects on a threepoint severity scale $(0,1$, or 2$)$ :

$\begin{array}{ll}\text { 0 points: } & 1 \text { point: } \\ \text { (1) Fully employed } & \text { Light job }\end{array}$

(2) Uses public trans- Light job

port

(4) Can cross road

(5) Can climb stairs

(6) Can dress

(7) Arise from chair

(8) Feeds himself

(9) Can turn over
(10) Not confined to chair

Six occupational therapy tests were given according to speed of performance, each on a six-point scale (0-5) giving a possible total of 30 points:

$$
\begin{aligned}
& \text { Threading beads } \\
& \text { Removing beads } \\
& \text { Peg board-large } \\
& \text { Peg board-small } \\
& \text { Handwriting } \\
& \text { Gait }
\end{aligned}
$$

